\title{
PLPP3 Gene
}

National Cancer Institute

\section{Source}

National Cancer Institute. PLPP3 Gene. NCI Thesaurus. Code C105941.

This gene is involved in the metabolism of diacylglycerol. 